DOI: $10.22363 / 2312-9220-2021-26-4-697-704$

УДК 070

Research article / Научная статья

\title{
Comparative Study \\ on Transmedia Awareness of Traditional Media Audiences and Social Media Users in Turkey and Ukraine
}

\author{
Can Bilgili(1)@ Olena I. Goroshko ${ }^{(2)}$ \\ (1) Istanbul Gedik University, \\ 1 Illkbahar St, Cumhuriyet, 34876, Kartal, Istanbul, Turkey \\ ${ }^{(2)}$ National Technical University "Kharkiv Polytechnic Institute" \\ 2 Kirpichov St, Kharkiv, 61000, Ukraine \\ can.bilgili@gedik.edu.tr
}

\begin{abstract}
The theory of mediatization focuses on discussions on the intertwining of the media with social institutions such as politics, family and religion, influencing and being affected by these structures. In general, mediatization refers to the social and cultural process in which a field or institution becomes to some extent dependent on the logic of the media (Hjarvard, 2011). Hjarvard draws attention to the processes of mediatization as a concept by cultural and social phenomena through the media, and their symbolic content is more or less under the influence of the media. The media is determinative on the fictional world with it produces and, on its audience (consumers). It influences, directs and shapes them through the discourse it produces. Mediatization is an important issue in the context of media literacy and especially transmedia methods. Because transmedia content practices and methods increase the mediatization effect and affect the orientations of the individual and society, especially when it comes to inadequacy in the context of media literacy. Therefore, this study focused on the awareness of the audience (consumers) about transmedia applications. It is seen that the studies conducted in the field of transmedia have developed in terms of content production methods, strategies and audience engagement. It is understood that there are not enough studies on subjects such as audience impacts or audience awareness. In this context and in this study, the competence of multimedia viewers who use social media and follow a traditional media tool to understand and be aware of the content transitions between different media tools has been examined. The television channel was chosen as the traditional media medium for the research study due to its widespread viewing.
\end{abstract} Ukraine

Keywords: transmedia storytelling, media audiences, social media, convergence, Turkey, 
Acknowledgements and Funding. We are particularly grateful for the assistance given by Ali Gizer - Research Consultant at AG Platform and member of ESOMAR, WAPOR, TUAD (Turkish Association of Researchers), AC and TUGIM (Entrepreneurs and Business Mentors Association) for survey layout development and data handling.

We also wish to acknowledge the help provided by Robert Holman as a native speaker of English in paper proofreading.

Conflicts of interest. The authors declare that there is no conflict of interest.

Article history: submitted: June 2, 2021; accepted: June 20, 2021.

For citation: Bilgili, C., \& Goroshko, O.I. (2021). Comparative study on transmedia awareness of traditional media audiences and social media users in Turkey and Ukraine. RUDN Journal of Studies in Literature and Journalism, 26(4), 697-704. doi: 10.22363/23129220-2021-26-4-697-704

\title{
Сопоставительный анализ трансмедийной осведомленности аудиторий традиционных СМИ и социальных медиа в Турции и Украине
}

\author{
Дж. Билгили ${ }^{(1)}{ }^{凶}$, Е.И. Горошко ${ }^{(2)}$ \\ (1) Стамбульский Гедык университет, \\ Туриия, 34876, Стамбул, Картал, Чумхурие, ул. Илкбар, 1 \\ (2) Национальный технический университет \\ «Харьковский политехнический институт», \\ Украина, 61000, Харьков, ул. Кирпичова, 2 \\ $\checkmark$ can.bilgili@gedik.edu.tr
}

\begin{abstract}
Аннотация. Тема трансмедиа становится все более актуальной для современных исследований медиа как с точки зрения производства контента, так и аудитории СМИ. Развитие новых медийных технологий изменило распространение контента в сфере массовых коммуникаций, а также его влияние на людей и общество. Сегодня мы продолжаем получать и генерировать социальные смыслы, имеющие коммерческие, политические или социальные цели, практически от любого средства массовой информации с разным содержанием посредством именно трансмедийного повествования. Проведенный теоретический анализ показал, что исследования в области трансмедиа, развивались интенсивно с точки зрения методов производства контента, стратегий и взаимодействия с аудиторией. Однако вопрос влияния аудитории или осведомленность аудитории и их взаимоотношения с трансмедийными историями является недостаточно изученным. Данное исследование направлено на выявление осведомленности аудитории и потребителей о содержании трансмедийных историй в контексте медиаграмотности, особенно в контексте использования традиционных и новых медиа в сопоставительном аспекте (турецко-украинские параллели).
\end{abstract}

Ключевые слова: трансмедийное повествование, медийная аудитория, социальные медиа, конвергенция, Турция, Украина 
Благодарности и финансирование. Мы особенно благодарны Али Гизеру консультанту по исследованиям AG Platform и члену ESOMAR, WAPOR, TUAD (Tyрецкая ассоциация исследователей), AC и TUGIM (Ассоциация предпринимателей и бизнес-наставников) за помощь в разработке макета опроса и обработке данных.

Мы также хотим поблагодарить Роберта Холмана как носителя английского языка за помощь в корректуре данной статьи.

Заявление о конфликте интересов. Авторы заявляют об отсутствии конфликта интересов.

История статьи: поступила в редакцию - 2 июня 2021 г.; принята к печати 20 июня 2021 г.

Для цитирования: Bilgili C., Goroshko O.I. Comparative study on transmedia awareness of traditional media audiences and social media users in Turkey and Ukraine // Вестник Российского университета дружбы народов. Серия: Литературоведение. Журналистика. 2021. Т. 26. № 4. С. 697-704. doi: 10.22363/2312-9220-2021-26-4-697-704

\section{Understanding the transmedia audience (or consumer)}

In general, media professionals, as content producers, have sufficient equipment and knowledge about transmedia applications. They have method and strategy skills on issues such as content production, content reinforcement with cross-media applications, presenting complementary content with different media tools, ensuring participation and experience. However, when the studies in the field are taken into account, there are not many studies on the level of awareness of the audience about reaching them through different media and transmedia methods. This aspect of the study is expected to contribute to the field.

According to Scolari (2009), on whose views we base our study in the context of the media consumer, there are three types of media consumers [25]. Such consumers can also be considered as a chronological perspective on the media and the development of the media consumer. In this sense, the media consumer of the first group is the consumer of a single text. In the second group, there are users of a certain channel. These consumers consume every single text transmitted through a channel.

Transmedia consumers are in the third group. Transmedia consumers are on the move between channels and platforms where the story is presented. They do not limit themselves to only a part of the story and try to capture all the narratives and texts to explore the world of the story [7].

With the development of social media usage habits of viewers who follow traditional media tools, media consumption behaviors and tendencies are also changing. Today's media consumers may not have sufficient awareness of the transmedia content they are exposed to while following many media content with different mass media (Figure 1). In addition, if the watched content redesigns the perception of reality, this issue becomes even more important. 


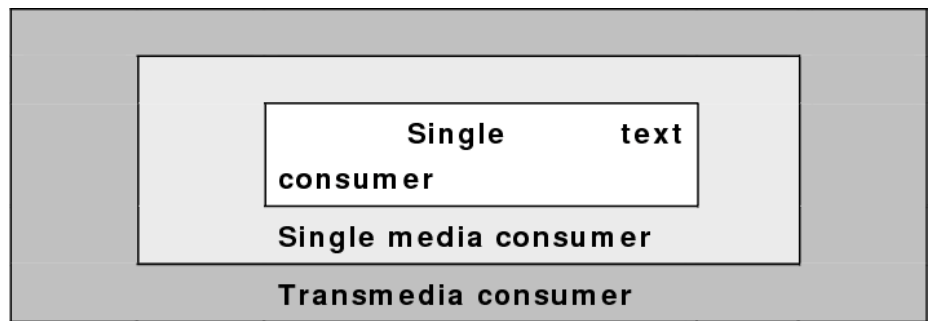

Figure 1. Types of Media Consumer and Transmedia Consumer S ource: [25. P. 597]

\section{Research problem and methodology}

The study seeks answers to the following two fundamental questions:

a) Do social media users have an idea about the fictional nature of the media contents they follow daily?

b) Do social media users have awareness about transmedia contents and applications?

Within the scope of the research, the quantitative research method was preferred. The answers given by people who both have social media accounts and watch television were evaluated as research data.

The questionnaire form of the research, in which the trend and behavior data on media use was also obtained, was shared online. In order to get the views on Transmedia awareness, which is important for the subject of the research, and to generate data, some suggestions were made to the participants with a Likert scale and their opinions were asked.

The awareness levels of the participants were questioned on the subjects in the scale consisting of 13 randomly ordered items.

Social media users are analyzed transmedia awareness level trough the Turkish-Ukrainian perspective within different media and different cultural contexts with the propositions in the Likert scale.

In the study, in which the awareness levels of the subjects with different characteristics such as age, gender and education, regarding transmedia content were examined, the awareness levels of the participants were also obtained according to the social media networks they used.

The research includes only a limited observation based on the comparison of two media consumption areas and two countries. It is expected to be a source for future transmedia audience research.

\section{Findings}

The answers of the participants in the research were evaluated and the data of 561 people from Turkey and 356 people from Ukraine were taken into account. 
Considering the participant profile; 76.5 percent of the participants from Turkey and 52.8 percent of the participants from Ukraine are women. The proportion of male participants in Ukraine is $45.2 \%$, higher than the participants in Turkey. While the majority of Ukrainian respondents are in the age group of 15-19, 34.58 percent of respondents from Turkey are in the age group of 40-49. It is seen that the participants from Turkey are mostly at "University (3-4 years), Higher Education (3-4 years)" and Postgraduate levels. Respondents from Ukraine were found to focus on "Full secondary education (10-12 years)".

Within the scope of the research, particularly, with the 8th question, on which the Likert scale was applied, the opinions of the participants on the reality and propaganda power of the contents in these media channels were taken and their awareness levels on transmedia content practices in both media areas were questioned.

Although many results have been obtained, the following findings have been reached when we evaluate some data in terms of our subject:

- Turkish viewers watch television at a higher rate than Ukrainian viewers.

- It is understood that the media consumers of both countries have a similar tendency in their use of social media.

- When a comparison is made between both countries, it is understood that media consumers in Turkey are more dependent on social media as they are on television.

- The proposition "Television is a propaganda tool" was accepted for media consumers in both countries.

- It is understood that Turkish media consumers agree more with the proposition that television is a fiction than Ukrainians.

- Media consumers in both countries largely agree with the proposition that television and social media are used to promote certain ideas in public. Accordingly, both countries emphasize that there is a serious transition between media consumers, television and social media, and real life.

One of the scale statements in the research form, "I come across different types of content on television and social media to support certain ideas" is an important proposition for our study. It is useful to make some determinations by comparing this expression with other scale expressions. In this context, if an evaluation is made on people who "agree" or "disagree" with other propositions, the participants mostly state that they encounter different types of content on television and social media to support certain ideas. The view that certain thoughts are expressed with different types of content in media environments and tools was put forward by the participants. Awareness is high.

\section{Discussion and conclusions}

Within the scope of the study, by taking the opinions of the participants, the effects of the contents in television and social media, which are different types of 
media, in terms of reality/fiction, propaganda and their power to direct life, and participant levels of transmedia awareness were questioned.

The issue of "awareness" even gains more importance within the context of mediatization and media literacy, especially considering the effect of the transmedia storytelling method, in which certain ideas and trends are marketed, on the media consumer.

The people participating in the research have a very high opinion that the different types of content they follow on social media and television are organized in order to support a certain thought.

However, this awareness should not be considered as having knowledge about "Transmedia" and being aware in this way. With this study, it can be argued that only the participants' awareness of exposure to transmedia applications is high. In addition, it is seen that the participants have a high awareness of the power of television or social media content to be fiction, contain propaganda and direct their life and thinking.

Within the framework of the research, the participants were also asked whether they encountered an idea presented by a TV program (series, news, entertainment program, etc.) in their social media posts. At this stage, it is targeted to understand the awareness of social media users on social media of transmedia content in the context of media convergence, regardless of content type. While 46.7 percent of the participants from Turkey gave the answer "Largely agree", this rate was 23.3 percent for the participants from Ukraine. Respondents from Turkey seem to have a higher level of awareness of transmedia content.

This research shows that the influence of transmedia in the context of mediatization is great. However, this study should be considered as a pioneering study for transmedia awareness research.

In the context of media literacy and mediatization in terms of our subject, it is predicted that studies on the awareness of media consumers will become more and more important, especially considering the impact and prevalence of transmedia applications in terms of constructing reality and placing certain thoughts.

\section{References / Библиографический список}

[1] Crossmedia (2021). Retrieved May 7, 2021, from https://www.tlu.ee/en/node/2178

[2] Dönmez, M., \& Güler, S. (2016). Transmedia Storytelling "Doritos Akademi" Study Case. Visionary Magazine, 7(16), 155-175.

[3] Dziubko, A.V. (2020). Ukraïns'ki revoljuciï u transmedijnomu storitelingu: avtors'kij prockt. [Ukrainian Revolution in Transmedia Storytelling] MA Thesis. VNZ «Ukraïns'kij katolic'kij universitet». L’viv. Retreived May 7, 2021, from https://er.ucu.edu.ua/bitstream/handle/1/2326/Dziubko_Ukrainski\%20revoliutsii\%20u\% 20transmediinomu.pdf? sequence $=1 \&$ isAllowed $=y-7 \overline{6}$ c. (In Ukrainian)

[4] Gambarato, R.R. (2013). Transmedia project design: Theoretical and analytical considerations. Baltic Screen Media Review (pp. 81-100).

[5] Gambarato, R.R., Lapina-Kratasyuk, E.G., \& Moroz, O.V. (2017). Transmedia storytelling panorama in the Russian media landscape, Shagi / Steps, 3(2), 20-46. (In Russ.) 
Гамбарато Р.Р., Лапина-Кратасюк Е.Г., Мороз О.В. Панорама российских трансмедиа: опыт картирования мультиплатформенных инициатив // Шаги. 2017. Т. 3. № 2. C. 20-46.

[6] Gambarato, R., \& Lapina-Kratasyuk, E. (2016). Transmedia Storytelling Panorama in the Russian Media Landscape. The Russian Journal of Communication, 8(1), 1-16.

[7] Gürel, E., \& Tiğli, O. (2014). New World Created by Social Media: Transmedia Storytelling. Journal of Media Critiques, 1(1), 35-65. DOI: 10.17349/jmc114102. Retrieved May 7, 2021, from https://www.researchgate.net/publication/276239031_ New_World_Created_by_Social_Media_Transmedia_Storytelling

[8] Hjarvard, S. (2011). The mediatization of religion: Theorising Religion, Media and Social Change. Culture and Religion, 12(2), 119-135.

[9] Hvorostina, O.V. (2021). Strukturni modeli transmedijnih pro€ktiv u zhurnalistici [Structural Models of Transmedia Projects in Journalism]. Naukovi zapiski Institutu zhurnalistiki [Scientific Papers of Journalism Institute], 2(75), 70-84. Retrieved May 7, 2021, from http://www.scientific-notes.com/archives/813 (In Ukrainian)

[10] Ivanishina, L. (2014). U mirnij chas poljagli za Ukraïnu [They Gave their Lives for Ukraine in Peacetime] [Elektronnij resurs]. Kinoteatr. Retrieved May 7, 2021, from https://ktm.ukma.edu.ua/show_content.php?id=1684.

[11] Jenkins, H. (2016). Convergence culture: where old and new media collide. New York: New York University Press.

[12] Jenkins, H. (2007). Transmedia Storytelling 101. The Official Weblog of Henry Jenkins. Retrieved May 7, 2021, from http://henryjenkins.org/2007/03/transmedia_storytelling _ 101.html.

[13] Kalinov, K. (2017). Transmedia Narratives: Definition and Social Transformations in the Consumption of Media Content in the Globalized World. Postmodernism problems, $60-68$.

[14] Kinder, M. (1991). Playing with Power in Movies, Television, and Video Games: From Muppet Babies to Teenage Mutant Ninja Turtles (pp. 38-119). Berkeley and Los Angeles: University of California Press.

[15] Manovich, L. (2018). Jazyk novyh media [New Media Language]. Moskva: Ad Marketing Press.

[16] Manovich, L. (2014). Software is the Message. Journal of Visual Culture, 13(1), 79-81.

[17] McCredie, N. (2015). Weaving a Story World Web, Sydney: Macquarie ICT Innovations Centre.

[18] Media Convergence. (2021). Retrieved May 7, 2021, from https://leverageedu.com/blog/ media-convergence.

[19] Moloney, K. (2011). Transmedia Journalism as a Post-Digital Narrative. ATLAS (pp. 137). Retrieved May 7, 2021, from http://atlas.colorado.edu/wp-content/uploads/2015/ 04/ATLAS-Tech-Report-2102_11_02.pdf

[20] Moloney, K. (2014). Multimedia, Crossmedia, Transmedia... What's in a name? Transmedia Journalism. Retrieved May 7, 2021, from https://transmediajournalism.org/ 2014/04/21/multimediacrossmedia-transmedia-whats-in-a-name

[21] Negroponte, N. (1978). Archive for Nicholas Negroponte. Retrieved May 7, 2021, from https://multimediaman.blog/tag/nicholas-negroponte/.

[22] Oblichchja \#VABYLON'13. (2014). Ljudi, jaki tvorjat' kinoprotest. Chastina 2 [Faces \#VABYLON'13. People who are Making Movie Revolt. Part 2]. Ukraïns'ka pravda. Zhittja [Ukrainian Life]. Retrieved May 7, 2021, from https://life.pravda.com.ua/ukr/ culture/2014/03/4/155363/. (In Ukrainian)

[23] Pil'gun, M.A. (2015). Transmedia Storytelling: perspektivy razvitija mediateksta [Transmedia Storytelling: Mediatext Development Perspectives]. Jelektronnyj nauchnyj 
zhurnal "Mediaskop" [Research E-Journal Mediaskop], (3), 2-12 Retrieved May 7, 2021, from http://www.mediascope.ru/1773 (In Russ.)

Пильгун M.A. Transmedia Storytelling: перспективы развития медиатекста // Медиаскоп. 2015. № 3. С. 2-12. URL: http://www.mediascope.ru/1773

[24] Sar1, G. Abant. (2017). Journal of Cultural Studies (AKAR), 2(4), 71-79. (In Turkish)

[25] Scolari, C.A. (2014). Transmedia storytelling: new ways of communicating in the digital age. AC/E digital culture Annual Report, (6), 69-79.

[26] Scolari, C.A. (2009). Transmedia storytelling: Implicit consumers, narrative worlds, and branding in contemporary media. International Journal of Communication, (3), 586606.

[27] Sokolova, N.L. (2011). Transmedia i «interpretativnye soobshhestva» [Transmedia and Interpretive Society]. Mezhdunarodnyj zhurnal issledovanij kul'tury [International Journal of Cultural Research], (3-4), 16-21. (In Russ.)

Соколова Н.Л. Трансмедиа и «интерпретативные сообщества» // Культурная история медиа. 2011. № 3(4). С. 16-21.

[28] The Concept of Media Convergence. (2014). Retrieved May 7, 2021, from https:// ololadeganiyualabi.wordpress.com/2014/03/11/the-concept-of-media-convergence/

\section{Bio notes:}

Can Bilgili, CEO \& Founder of World Experience Campus, Professor of Media and Communication, Department of Visual Communication Design at Gedik University, Istanbul, Turkey. ORCID: 0000-0002-7581-9622; e-mail: can.bilgili@gedik.edu.tr

Olena I. Goroshko, Professor, Head of Cross-Cultural and Media Communication Department National Technical University "Kharkiv Polytechnic Institute", Kharkiv, Ukraine. ORCID: 0000-0002-8592-1022; e-mail: olena.goroshko1965@gmail.com

\section{Сведения об авторах:}

Джан Билгили, генеральный директор и основатель World Experience Campus, профессор медиа и коммуникаций, факультет дизайна визуальных коммуникаций Университета Гедык, Стамбул, Турция. ORCID: 0000-0002-7581-9622; e-mail: can.bilgili@ gedik.edu.tr

Елена Игоревна Горошко, профессор, заведующая кафедрой межкультурных и медийных коммуникаций Национального технического университета «Харьковский политехнический институт», Харьков, Украина. ORCID: 0000-0002-8592-1022; e-mail: olena.goroshko1965@gmail.com 